\title{
Epistemologi Thomas S. Kuhn: Kajian Teori Pergeseran Paradigma dan Revolusi Ilmiah
}

\author{
Iftahul Digarizki ${ }^{1}$, Arif Al Anang ${ }^{2}$ \\ ${ }^{1}$ Universitas Islam Negeri Sunan Kalijaga \\ ${ }^{2}$ Universitas Gadjah Mada \\ iftahul17rizki@gmail.com \\ radenarifmasduki@gmail.com
}

\begin{abstract}
Abstrak
Ketika sebuah ilmu tidak perlu dikritik, ketika kemapanan ilmu menjadi hal yang sakral, dan ketika sebuah paradigma menindih dan menyelimuti semua paradigma lainnya. Kuhn berangkat dari kritik terhadap paradigma yang dianggap absolut seolah paradigma tersebut menjadi primadona diantara paradigma lainnya. Dari problem tersebut lahirlah apa yang disebut Paradigm Shift dan Revolution Scientific. Tulisan ini melihat epistemologi pemikiran Kuhn terkait revolusi saintifiknya dengan metode deskriptif analitis. Kuhn mengatakan pada fase normal science, paradigma yang sakral tidak dilihat secara kritis. paradigma tersebut diterima begitu saja tanpa kritik. Kemudian pada satu titik muncullah anomali yakni ketika paradigma lama tidak mampu untuk menjawab tantangan zaman yang terus mengalir deras dan masuk pada fase krisis. Pada fase krisis, paradigma lama bertarung dengan paradigma baru dan saling menjatuhkan. Kuhn melihat objektivitas keilmuan dalam perkembangan pengetahuan sebagai sesuatu yang tidak bisa bersifat tunggal (komulatif). Dengan demikian, sebenarnya tidak terdapat ilmu yang benar-benar bertahan terus-menerus dan menjadi absolut/abadi disebabkan sebuah paradigma pasti berada karena tuntutan dari dinamika sosial tertentu.
\end{abstract}

Kata Kunci: Epistemologi; Pergeseran Paradigma; Revolusi Saintifik

\begin{abstract}
When a science does not need to be criticized, when the establishment of science becomes a sacred thing, and when a paradigm overlap and envelop all other paradigms. Kuhn departed from the criticism of the paradigm that was considered absolute as if the paradigm had been excellent among the other paradigms. From this problem was born what was called Paradigm Shift and Revolution Scientific. This paper looks at the epistemology of Kuhn's thought related to his scientific revolution with descriptive-analytical methods. Kuhn said in the normal phase of science, the sacred paradigm was not seen critically. the paradigm is taken for granted without criticism. Then at one point came the anomaly that is when the old paradigm was unable to answer the challenges of the times that continued to flow freely and enter the crisis phase. In the crisis phase, the old paradigm fights with the new paradigm and overthrows one another. Kuhn sees scientific objectivity in the development of
\end{abstract}


knowledge as something that cannot be single (cumulative). Thus, in fact there is no science that really persists and becomes absolute / eternal because a paradigm must exist because of the demands of certain social dynamics.

Keywords: Epistemology; Paradigm Shift; Scientific Revolution

\section{Pendahuluan}

Tulisan ini dilatarbelakangi oleh problematika ilmiah yang mengalami perkembangan terus-menerus. Pada setiap rentetan perkembangan tersebut terjadilah berbagai polemik, kritik, dan kontroversi. Keunggulan ilmu yang datang belakangan mengkritik keilmuan sebelum-sebelumnya. Fenomena yang terus-menerus ada sebagai sebuah konsekuensi kehidupan menjadikan sebuah teori terus diasah dan diuji. Kebenaran ilmiah tidak lagi menjadi sesuatu yang bersifat sakral akan tetapi niscaya untuk terus dipertanyakan demi menghindari adanya reduksi terhadap gejala-gejala sosial yang faktual terjadi dikalangan masyarakat (Anang, 2020: 69). Salah satu filsuf yang memaksa dirinya untuk fokus dalam persoaln tersebut ialah Thomas S. Kuhn.

Dalam aliran kefilsafatan Thomas S. Kuhn ditempatkan dalam kelompok para filsuf sains rasionalis. Thomas S. Kuhn merupakan filsuf yang lahir pasca empiris layaknya Paul Feyerabend, dan Imre Lakatos. Untuk itu, dalam tulisan ini penulis menyajikan bagaimana epistemologi pemikiran seorang Thomas S. Kuhn terutama terkait Paradigm Shif dan Scientific Revolution.

Penelitian terdahulu yang sudah dilakukan antara lain yaitu; penelitian tentang "Pemikiran Thomas S. Kuhn Teori Revolusi Paradigma. Islamadina: Jurnal Pemikiran Islam" (Kesuma \& Hidayat, 2020; 166-187). Penelitian Putri, \& Iskandar (2020) tentang "Paradigma Thomas Kuhn: Revolusi Ilmu Pengetahuan dan Pendidikan". Penelitian Almas, (2018; 89-106) tentang "Sumbangan Paradigma Thomas S. Kuhn dalam Ilmu Dan Pendidikan (Penerapan Metode Problem Based Learning dan Discovery Learning)”. Penelitian tentang “Pemikiran Thomas Kuhn dan Relevansinya terhadap Keilmuan Islam” (Ulya \& Abid, 2015; 249-276). Penelitian Nurkhalis, N. (2012; 79-99) tentang “Konstruksi Teori Paradigma Thomas S. Kuhn”.

Penelitian tersebut di atas secara umum berbicara tentang pemikiran Thomas S. Kuhn, tetapi tidak ada yang secara khusus menjelaskan tentang teori pergeseran paradigma dan revolusi ilmiah sebagaimana dilakukan pada kajian ini. Hal ini berarti 
jelas posisi penelitian ini dengan penelitian terdahulu yang sudah dilakukan orang lain. Hal ini berarti bahwa urgensi penelitian ini menjadi penting dalam memandang teori pergeseran paradigma dan revolusi ilmiah Thomas S. Kuhn.

\section{Metode Penelitian}

Penelitian ini menggunakan penelitian kepustakaan dengan merujuk pada sumber buku dan artikel serta opini sebagai sumber utama (Zeid, 2014) dengan metode deskriptif analitis sebagai tahapan penelitian (Sudjana dan Ibrahim, 2007). Data didapatkan dari sumber artikel dan jurnal, buku, dan berita yang ada di media massa. Penelitian ini menggunakan metode analisis deskriptif untuk menganalisis data (Sugiyono, 2014). Data ditinjau dan diselidiki dalam tiga tahap; umum, eksploratif, dan fokus belajar. Ini merupakan bahan yang komprehensif dalam upaya meringkas temuan dan menyimpulkan hasilnya. Data dideskripsikan kemudian dianalisis dengan mengacu pada teori yang digunakan sehingga didapatkan gambaran atas fokus penelitian.

\section{Pembahasan}

\section{Definisi dan Cakupan Epistemologi}

Dalam sejarah fislafat, terkait epistimologi memeroleh porsi yang besar sehingga definisi epistimologi masih diperdebatkan baik dalam ranah lafaznya maupun substansi (Anang, 2019: 100). Perdebatan tersebut bertujuan untuk masuk dalam ranah substansi sejauh mungkin. Sebagaimana penjelasan P.haryono Hadi menerangkan bahwa epsitimologi merupakan salah satu cabang filsafat yang mempelajari dan mencoba menentukan kodrat dan skope pengetahuan, pengandaian-pengandaian dan dasarya, serta pertanggungjawaban atas pernyataan mengenai pengetahuan yang dimiliki (Qomar 2006: 3). Melihat definisi diatas, menurut penulis bahwa epistemologi berkaitan dengan fakta, sedangkan epistemologi bagi beberapa filsuf lainnya bahwa epistemologi juga berkaitan dengan hal-hal yang abstrak. Pada akhirya, dari kedua perdebatan tersebut yang melahirkan dua aliran yakni relaisme dan idealisme.

Epistemologi sebagai cabang dari filsafat menjadi dilema bagi banyak filsuf dan cendikiawan. Menentukan ruang lingkup atau cakupan dari epsitemologi saja menuai perdebatan panjang, bahkan belum final untuk cakupannya sendiri (Anang, 2020: 2- 
3). Azyumardi Azra menyebut bahwa "epistemologi merupakan ilmu yang membahas keaslian, pengertian, struktur, metode, dan validitas ilmu pengetahuan" (Qomar 2006: 4). Mengenai cakupan dari epistemologi tedapat perdebatan akademis yang sangat luas. Terlepas dari perdebatan teersebut, penulis mengambil sebuah poin yang menjadi titik tolak tulisan ini yakni mengenai validitas pengetahuan. Bertolak dari hal tersebut maka kita akan bertanya, apa ilmu itu? dari mana asalnya, apa sumberya, hakikatnya, seberapa besar mendekati kebenaran, dan dimana letak batasan dari ilmu tersebut?

\section{Biografi dan Konsep Paradigma Kuhn}

Thomas S. Kuhn lahir pada tanggal 18 Juli 1922 di Cincinnati Ohio, USA dari keluarga Yahudi. Kuhn memperoleh gelar sarjana di bidang ilmu fisika dari Universitas Harvard dengan summa cumlaude pada tahun 1943. Gelar master dalam ilmu fisika di Harvard univercity pada tahun 1946 dan Ph. D pada tahun 1949 dalam bidang yang sama ilmu fisika (Sonjoruri, 2008: 224). Sebelum mendalami ilmu-ilmu sosial humaniora Kuhn terlebih dahulu tenggelam dalam pekatnya ilmu fisika. Setelah menjadi pakar dalam ilmu fisika khun kemudian mempelajari sejarah ilmu dan filsafat ilmu (Zubaedi, 2007: 200).

Karya pertamanya ialah The Copernican Revolution (1957) dan karya lainnya dari Kuhn terdapat Black-Body Theory and the Quantum Discontinuity (1979). Namun, Thomas S. Kuhn dikenal oleh masyarakat akademis secara luas dengan karya fenomenalnya The Stucture of Scientific Revolutions (1962). Dengan karyanya tersebut, telah terjual berjuta ekstemplar dan menjadi salah satu topik utama tokoh yang paling kontroversial pada abad ke-20 (Sharrock dan Read, 2002). Tahun 1983 Kuhn mendapat gelar Laurence S. Rockefeller profesor filsafat di MIT. Thomas Samuel Kuhn wafat pada hari Senin, 17 Juni tahun 1996 karena kanker. Setelah kematiannya, The Road Since Structure, sebagai kumpulan tulisan Kuhn tahun 1970-1993, diterbitkan pada tahun 2000 (Sonjoruri, 2008: 225).

Berdasarkan biografi tersebut Kuhn melahirkan sebuah paradigma yang menguncang beberapa ilmuwan sebelumnya. Baerikut penulis menjelaskan konsep paradigma menurut Kuhn: Pusat dari pemikiran Kuhn ialah apa yang disebut Paradigm. Menurut Kuhn definisi Paradigm mendekati sains normal, dimaksud ialah gabungan variabel yang membentuk teori-teori, dalil, dan sebagainya. Dengan kata 
lain, kerangka referensi yang menjadi dasar bagi teori-teori maupun praktek ilmiah dalam periode tertentu (Zubaedi, 2007: 201). Dengan demikian paradigma merupakan suatu pandangan dasar tentang yang menjadi bahasan pokok tentang apa yang seharusnya, mencakup apa yang mestinya ditanyakan dan bagaimana memunculkan solusi atas permasalahan yang terjadi disertai dengan deskripsi ilmiah.

Thomas Kuhn menjelaskan bahwa paradigma sebagai beberapa contoh praktik ilmiah aktual yang diterima. Termasuk contohnya ialah hukum, teori, aplikasi, dan instrumen yang merupakan hasil dari kesepakatan bersama dan menjadi rujukan utama dalam penelitian ilmiah (Ulya dan Abid, 2015: 255). Dalam penelitian ilmiah Kuhn membagi karakteristik menjadi dua karakter, yakni pertama, menawarkan aspek dan unsur baru atau bisa disebut keluar dari metode-metode yang telah ada atau telah mapan sebelumnya; kedua, menawarkan persoalan-persoalan baru yang masih terbuka dan belum diselesaikan (Kuhn, 1962: 10).

Menurut Kuhn objektivitas ilmu tidak bersifat otoritatif hanya sebatas sebuah justifikasi kebenaran. Inilah landasan epistimologis yang mengkritik keyakinan manusia terhadap kebenaran suatu pengetahuan atau pengetahuan yang mutlak sebagai representasi realitas dan fenomena. Jadi, paradigma tidak selalu terikat pada sebuah nilai benar atau salah. Namun sebuah paradigma punya aspek-aspek lebih yang bisa menjadi jembatan munculnya paradigma baru. Dalam artian, sebuah paradigma mestinya tidak mengandung sebuah kebenaran akan tetapi terdapat aspek aksiologis yakni kebermanfaatan bagi manusia dan lingkungannya. Inilah yang menjadi titik munculnya anomali, sains yang disepakati benar oleh masyarakat ternyata butuh penyesuaian dengan kondisi yang terus-menerus berjalan dan memunculkan persoalan-persoalan baru.

Berdasarkan penjelasan diatas, kebenaran ilmiah pun berubah-ubah secara revolusioner. Kemajuan ilmu pengetahuan sampai pada tahap kompleks, bahwa kemajuan tersebut ditandai tidak hanya melalui dan menemukan fakta-fakta ilmiah akan tetapi keilmuan ilmiah juga terus berkembang. Kemudian Thomas Kuhn membagi paradigma dalam beberapa tipe paradigma, yakni paradigma metafisik, paradigma sosiologis dan paradigma konstruk. Berikut penjelasan secara singkat beberapa tipe tersebut, antara lain: 


\section{a. Paradigma Metafisik}

Paradigma metafisik merupakan paradigma yang menjadi konsesus terluas dan membatasi bidang kajian dari satu bidang keilmuan saja, sehingga ilmuan akan lebih terfokus dalam penelitiannya. Paradigma metafisik ini memiliki beberapa fungsi: Pertama, Untuk merumuskan masalah ontologi (realitas/ objek kajian) yang menjadi objek penelitian ilmiah, Kedua, Untuk membantu kelompok ilmuan tertentu agar menemukan realitas/objek kajian (problem ontologi) yang menjadi fokus penelitiannya, Ketiga, Untuk membantu ilmuan menemukan teori ilmiah dan penjelasannya tentang objek yang diteliti.

b. Paradigma Sosiologi

Pengertian paradigma sosiologi ini dikemukakan Masterman sebagai konsep eksemplarnya Kuhn. Ini berkaitan dengan kebiasaan yang terus menerus, keputusankeputusan dan aturan umum serta hasil penelitian yang dapat diterima secara umum di masyarakat.

c. Paradigma Konstruk

Paradigma konstruk adalah konsep yang paling sempit dibanding kedua paradigma di atas. Contoh pembangunan reaktor nuklir merupakan paradigma konstruk dalam fisika nuklir dan mendirikan laboratorium menjadi paradigma konstruk bagi ilmu psikologi eksperimental. Paradigma konstruk dalam memahami realitas khususnya realitas sosial budaya bersifat plural (multiple realities) dan dikonstruksi. Sehingga, para ilmuwan memahami realitas dari ontologi yang relatif berdasarkan perspektif, kerangka teori dan paradigma tertentu. Sehingga, dalam pengembangannya interpretasi dan kreativitas peneliti menjadi vital karena menjadi bagian dari proses merekonstruksi (Ulya dan Abid, 2015: 256-258).

Berdasarkan penjelasan tersebut, secara umum Kuhn membagi paradigma menjadi dua paradigma utama, yaitu paradigma ilmiah dan paradigma alamiah:

a. Paradigma Ilmiah

Paradigma ilmiah memiliki dua cakupan yaitu fakta sosial dan perilaku sosial. Paradigma fakta sosial menunjuk kepada faktor dari luar diri manusia yang membuat dirinya melakukan sesuatu dengan tujuan dapat mengimbangi perilaku di luar dirinya, sehingga perilaku seseorang dapat dikontrol. Fakta sosial meliputi norma-norma, nilai- 
nilai, adat istiadat dan aturan-aturan yang bersifat memaksa dan mengikat. Paradigma fakta sosial ini dipelopori oleh Emile Durkheim. Fokus kajian dalam penelitian sosiologi meliputi struktur sosial dan pranata sosial.

Sekilas dapat disimpulkan bahwa ada beberapa pokok pemikiran tentang fakta sosial antara lain:

1. Model yang digunakan sebagai basis teori fakta sosial adalah karya Emile Durkheim, khususnya The Rules of Sociological Method dan suicide

2. Teori fakta sosial lebih fokus pada struktur dan institusi sosial dan pengaruhnya terhadap pola fikir dan perilaku individu

3. Metode yang digunakan dalam paradigma fakta sosial adalah interview, kuesioner dan perbandingan sejarah

4. Terdapat beberapa teori yang dapat digunakan dalam menganalisa masalah sosial yang tergabung dalam paradigma fakta sosial, yaitu teori fungsionalisme fungsionalisme struktural, teori konflik, teori sosiologi makro dan teori sistem.

Sedangkan perilaku sosial menyatakan bahwa perilaku seseorang dapat dipicu oleh kondisi-kondisi tertentu. Dalam hal ini, perilaku seseorang ditentukan oleh stimulus yang datang dari luar. Stimulus tersebut dapat membuat individu berfikir dan berperilaku. Paradigma perilaku sosial meliputi tiga asumsi dasar bahwa: Pertama, perilaku manusia pada dasarnya dapat dikontrol, Kedua, Kepribadian manusia tidak dapat dijelaskan melalui mekanisme psikis id dan ego, Ketiga, perilaku manusia tidak ditentukan hanya oleh pilihan individual.

Paradigma perilaku sosial ini dalam ilmu psikologi dikenal dengan pendekatan behaviorisme dengan tokoh utamanya Burrhus Frederic Skinner. Sekilas dapat disimpulkan bahwa terdapat beberapa pokok pemikiran tentang perilaku sosial dalam beberapa hal berikut ini:

1. penganut dari paradigma perilaku sosial ini adalah Burrhus Frederic Skinner

2. Model penelitian yang digunakan menggunakan psikologi empiris-eksperimental dan psikologi behaviorisme

3. Menurut paradigma perilaku sosial bahwa kajian pokoknya meliputi perilaku individu yang tidak difikirkan dan teramati. Hal ini mengacu pada konsep reward dan punishman. Reward memicu perilaku yang diinginkan dan punishman memicu perilaku yang tidak diinginkan. 
4. Metode yang digunakan dalam paradigma perilaku sosial adalah metode eksperimen

5. Teori yang digunakan dalam perilaku sosial adalah teori sosiologi behavioral dan teori pertukaran

\section{b. Paradigma Alamiah}

Paradigma alamiah ini mengacu pada paradigma definisi sosial yang dimulai oleh Weber. Weber memusatkan perhatiannya tentang tindakan sosial dan interaksi sosial sosial. Tindakan sosial diartikan sebagai tindakan individu yang mempunyai makna atau arti subjektif bagi dirinya dan diarahkan kepada orang lain (Ulya dan Abid, 2015: 258-259). Menurut Weber tindakan sosial adalah tindakan individu yang mempunyai pemaknaan berdasarkan subyektivitas dirinya dan diarahkan pada orang lain. dalam artian dari dalam diri menuju luar diri. Sehingga, meurutnya mengarahkan sosiologi sebagai ilmu yang berusaha memaknai dan memahami tindakan sosial dan berbagai interaksi sosial untuk memperoleh penjelasan kausal. Maka, sosiologi kontemporer juga disebut sosiologi interpretatif (Upe, 2010: 68).

Definisi sosial ini tidak berpijak pada fakta sosial yang dianggap obyektif, yaitu struktur dan pranata sosial, tetapi pada proses berpikir manusia. Sehingga dalam memaknai realitas dan interaksi sosial, manusia diposisikan sebagai pelaku yang natural dalam mengekspresikan tindakannya. Sehingga, tindakan dan interaksi sosial terjadi karena kemauan individu dan masyarakat itu sendiri. Maka, tindakan sosial tersebut tidak terpusat pada struktur-struktur sosial, tetapi pada definisi bersama berdasarkan perspektif masing-masing individu dan kelompok sosialnya.

\section{Revolusi Saintifik Kuhn}

Kemunculan revolusi saintifik berawal dari adanya anomali terhadap teori-teori yang telah mapan. Anomali tersebut menjadi semakin miris apabila teori-teori yang telah mapan justru memburuk keadaan atau tidak dapat melahirkan solusi-solusi yang dibutuhkan pada periode-periode tertentu (Zubaedi, 2007: 204). Munculnya revolusi sains tidak sebanding dengan diterima atau tidaknya di kalangan para akademisi atau masyarakat sains. Sebab kebenaran yang diterima itu ialah hasil kesepakatan masyarakat sains terhadap sebuah penemuan baru. Sifat intersubjetifitas di kalangan 
masyarakat sains tidak bisa dipandang sebelah mata sebab salah satu sebab lahirnya revolusi sains itu letaknya juga pada anomali kesepakatan tersebut. jika sebuah penemuan baru tidak dapat melandasi riset ilmiah sebagai sebuah paradigma yang mapan maka dibutuhkan revolusi yang melahirkan teori-teori baru yang membantu memecahkan persoalan ilmiah tersebut (Zubaedi, 2007: 206).

Revolusi ilmiah merupakan konsep Thomas Kuhn yang didefinisikan sebagai perubahan drastis dalam tahap kemajuan dan perkembangan ilmu pengetahuan. Cakupannya sederhananya yakni paradigma lama diganti seluruh atau sebagiannya oleh paradigma baru yang dianggap berseberangan/bertentangan. Menurut Kuhn bahwa kemajuan ilmiah mempunyai sifat revolusioner, cepat dan drastis bukan maju secara komulatif. Dasar tersebut menunjukkan bahwa revolusi ilmiah non-kumulatif untuk menuju ke perkembangan episode baru yang mana sebuah paradigma yang lama diganti secara keseluruhan atau sebagian oleh yang baru dan menggantikannya, sehingga berefek adanya diferensiasi secara mendasar antara paradigma lama dan paradigma baru. Revolusi ilmiah dalam perspektif Kuhn terjadi melalui beberapa lompatan-lompatan radikal dan revolusioner seperti dijelaskan di bawah ini (Ulya dan Abid, 2015: 263-266).

Paradigm I $\rightarrow$ Normal $\rightarrow$ Anomalies $\rightarrow$ Crises $\rightarrow$ Revolution $\rightarrow$ Paradigm II; Science

\section{The revolutionary chatocter of paradgm shifts, ond the cyclcal inture of sclence (a echocratization of Kuha. 1970).}

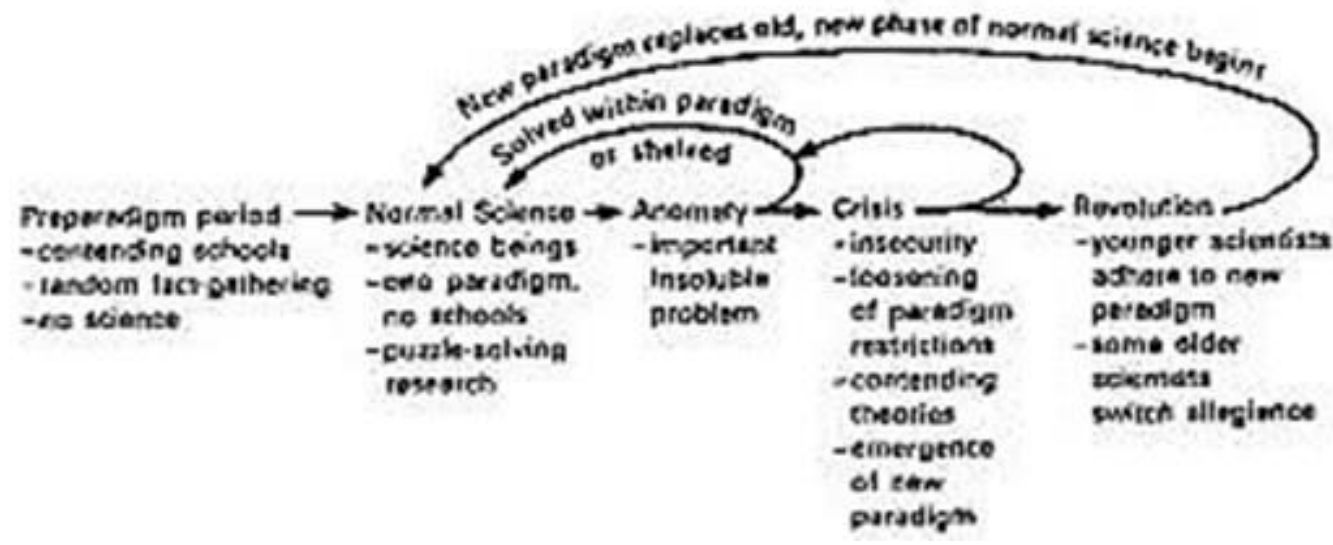

Model yang dikembangkan Thomas Kuhn pada paradigm I di awali dengan normal science. Namun sebelum masuk dalam langkah normal science tentu menempuh tahapan pra paradigma atau yang dimaksud ialah adanya kebenaran 
subjektif yang belim disepakati oleh masyarakat akademis. Kemudian dalam tahapan normal science terjadi akumulasi ilmu pengetahuan yakni para ilmuan berusaha mengembangkan paradigma yang oleh masyarakat akademis sebagai paradigma yang mutlak atau yang paling banyak berpengaruh. Kemudian dalam perkembangannnya paradigma lama mengalami kelumpuhan analitik atau tidak mampu memberi jawaban dan penjelasan terhadap banyaknya persoalan yang timbul.

Pada fase ini, para ilmuan tidak mampu lagi mengelak dari pertentangan karena terjadi banyak penyimpangan. Fase inilah yang disebut fase anomalies. Anomali merupakan salah satu faktor munculnya revolusi saintifik dan temuan-temuan baru. Untuk menemukan revolusi tersebut menurut khun harus menempuh dua gerak ilmiah yakni Puzzle Solving dan pemenemuan paradigma baru (Zubaedi, 2007: 204). Dalam puzzle Solving penekananannya tidak pada proses penemuan sebuah kebenaran akan tetapi lebih kepada memecahkan sebuah teka-teki.

Akibat yang muncul karena banyaknya anomali, maka lahir crisis. Pada fase krisis ini, paradigma mulai diragukan kebenarannya. Kemudian mengantarkan jalan untuk menuju fase revolusi (revolution). Pada fase revolusi inilah kemudian muncul paradigm II yang memiliki jawaban atas persoalan yang muncul dari paradigma sebelumnya. Siklus ilmiah tersebut menunjukkan tidak ada perubahan paradigma tanpa didahului krisis, namun demikian, paradigma sebelumnya yang dianggap tidak mampu menjawab persoalan yang ada dan terkesan bertentangan dengan paradigma baru, tetapi peran paradigma lama dianggap penting yang memungkinkan ilmuan untuk mengenali sesuatu yang anomali, karena bertentangan dengan harapan. Hal ini merupakan prasyarat penting bagi penemuan pengetahuan baru mengisi celah kekosongan atau ketidaktahuan.

Intinya bahwa sebuah anomali tidak dengan sendirinya cukup untuk perubahan paradigma dengan ketidaktahuan dan penolakan terhadap paradigma (falsifikasi). Kuhn menyebutkan bahwa kompleksitas tersebut sebagai syarat yang diperlukan untuk perubahan paradigm baru. Tapi krisis terungkap dengan cara berubah dari waktu ke waktu. Namun, proses peningkatan antara fakta dan teori adalah bagian dari normal science, sehingga anomali sebagai sebuah kegagalan harapan, hanya menyajikan puzzle (teka-teki) lain yang harus diselesaikan dengan eksplorasi dan konstruksi ilmiah. 


\section{Kesimpulan}

Penjelasan di atas dapat diperoleh beberapa kesimpulan yaitu; pertama, pemikiran Kuhn tentang paradigma menjadi fondasi awal dalam kerja filosofi ilmu. Di samping itu, paradigma Kuhn juga menjadi landasan teoritik ilmu pengetahuan. Kedua, terkait normal science yang memperlihatkan sebuah kondisi bahwa paradigma menjadi sedemikian dominan dan dipandang sebagai jalan yang mutlak kebenarannya justru perlu pertanyakan sebab sebuah teori yang mapan berhadapan dengan ruang dan waktu yang berjalan seolah mendobrak teori dari berbagai sisi. Ketiga, Scientific revolution merupakan lompatan dan perubahan secara drastis dan pada akhirnya melahirkan paradiga baru. Lompatan dan perubahan tersebut tidak justru mereduksi paradigma-paradigma sebelumnya akan tetapi menjadi jembatan akan lahirnya peradigma baru.

\section{Daftar Rujukan}

Al Anang, A. (2019). Sejarah Perkembangan Ilmu Pengetahuan dalam Islam. Fajar Historia: Jurnal Ilmu Sejarah dan Pendidikan, 3(2), 98-108.

Al Anang, A., \& Husein, A. (2020). Genealogi Aliran-Aliran Politik dalam Islam. Fajar Historia: Jurnal Ilmu Sejarah dan Pendidikan, 4(2), 68-79.

Al Anang, A., Husein, A., \& Rasyad, A. (2020). Pendidikan Agama Sebagai Branding di Media Sosial. Jurnal Humanitas: Katalisator Perubahan dan Inovator Pendidikan, 6(2), 1-10.

Almas, A. F. (2018). Sumbangan Paradigma Thomas S. Kuhn dalam Ilmu dan Pendidikan (Penerapan Metode Problem Based Learning dan Discovery Learning). At-Tarbawi: Jurnal Kajian Kependidikan Islam, 3(1), 89-106.

Ambo Upe, Damsyid. (2010). Asas-Asas Multiple Researches: dari Nornam K. Denzim hingga John W. Creswell dan Penerapannya. Yogyakarta: Tiara Wacana.

Husein, A., \& Anang, Arif Al. (2020). Memahami Al-Qur'an Kontemporer Antara Teks, Hermeneutika Dan Kontekstualisasi Terhadap Ayat Perbudakan. Jurnal Ulunnuha, 9(2), 120-135.

Kesuma, U., \& Hidayat, A. W. (2020). Pemikiran Thomas S. Kuhn Teori Revolusi Paradigma. Islamadina: Jurnal Pemikiran Islam, 166-187.

Nurkhalis, N. (2012). Konstruksi Teori Paradigma Thomas S. Kuhn. Jurnal Ilmiah Islam Futura, 11(2), 79-99. 
Putri, F. A., \& Iskandar, W. (2020). Paradigma Thomas Kuhn: Revolusi Ilmu Pengetahuan Dan Pendidikan. Nizhamiyah, 10(2).

Qomar, Mujamil. (2006). Epistemologi Pendidikan Islam; Dari Metode Rasional hingga Metode Kritik, Jakarta: Erlangga.

S. Kuhn, Thomas. (1962). The Structure of Scientific Revolution. Leiden: Instituut Voor Theoretische Biologie.

Sharrock, Wes. Dkk. (2002). Kuhn: Philosopher Of Scientific Revolution. United Kingdom: Polity Press with Blackwell Publishers.

Sudjana, Nana. Ibrahim, (2007). Penelitian dan Penelitian Pendidikan. Bandung: Sinar Baru Algensindo.

Sugiyono. (2014). Metode Penelitian Pendidikan Pendekatan Kuantitatif, Kualitatif, dan $R \& D$. Bandung: Alfabeta

Trisakti, S. B. (2008). Thomas Kuhn dan Tradisi-Inovasi dalam Langkah Metodologis Riset Ilmiah. Jurnal Filsafat, 18(3), 223-240.

Ulya, I., \& Abid, N. (2015). Pemikiran Thomas Kuhn dan Relevansinya terhadap Keilmuan Islam. Fikrah, 3(2), 249-276.

Zeid, Mestika. (2014). Metode Penelitian Kepustakaan. Jakarta: Yayasan Pustaka Obor Indonesia.

Zubaedi. (2007). Filsafat Barat. Yogyakarta: Ar-Ruzz Media. 